\title{
A Study of Past Research on Sŏngsan Fortress Wooden Tablets and an Examination of Excavated Wooden Tablet Documents
}

Nari Kang*

\section{Introduction}

The existence of inscribed wooden tablets (Mokkan, 木简) in Korea was first confirmed from the excavation of Anapji, but full-fledged research on wooden tablets began with the unearthing of wooden tablets from Sǒngsan Fortress in Haman. Since then, Kaya National Research Institute of Cultural Heritage has held an international academic conference, compiled information on wooden tablets from ancient Korea and published Han'gugǔi Kodae Mokkan (Wooden Tablets of Ancient Korea) and Han'guk Mokkan Chajǒn (Collection of Korean Wooden Tablets), and finally founded a research center for wooden tablets. Currently, over 600 wooden tablets have been discovered at Sŏngsan Fortress, accounting for nearly half of all wooden tablets from ancient Korea that have been discovered until today. Moreover, since Songsan Fortress became the largest treasure trove of Hach'al Mokkan (wooden tablets used as labels)

* Ph.D. Student, Department of Korean History, Korea University, Seoul, South Korea

1 Kungnip Ch'angwŏn Munhwajae Yŏn'guso (Changwon National Research Institute of Cultural Heritage), Han'gugǔi Kodae Mokkan (Ch'angwŏn: KCMY, 2004); Son Hwan Il, ed., Han'guk Mokkan Chajǒn (Ch'angwŏn: Kungnip Kaya Munhwajae Yŏn'guso, 2011). 
from the Silla dynasty, wooden tablets from the fortress have now become an important resource for the understanding of Silla in the sixth and seventh century, known as the Mid-Ancient Period.

Songsan Fortress in Haman is located at the apex of Chonam Mountain, which stands 139 meters tall across Kwangjŏng-ri and Koehang-ri in Kaya-ǔp, Haman-gun, South Kyǒngsang Province. Large-scale ancient tumuli of Ara Kaya leaders, such as the Marisan Tumuli, Nammunoe Tumuli, and Magapch'ong, are located within the three-kilometer radius of Songsan Fortress, and as a result this area is presumed to be a major political and military base of Ara Kaya. ${ }^{2}$ From 1991 to 2016, there have been a total of 17 excavations led by the Kaya National Research Institute of Cultural Heritage at Sorngsan Fortress. Of all the sections of the fortress, the East Fortress Wall (tongsǒngbyǒk) section was the deepest and most vulnerable to collapse, as it was built in the deep valley of Chonam Mountain. To protect themselves against geographical vulnerabilities, people of Silla built a drainage system with various drainage facilities and stone-filled drains, using a traditional construction technique that involved convering the ground with dried grass and leaves and stamping the soil to make the foundation firm. ${ }^{3}$

Wooden tablets uncovered at Sorngsan Fortress were intentionally interred together at the place where the "leaf-paved" layer (created with the above construction method) was laid to reinforce the East Fortress Wall. Around 1992, two tablets were discovered in the leaf-paved layer near

2 Ara Kaya was one of several 'Kaya' countries, also called 'Asiryangguk', 'Anagaya', 'Anyaguk' and 'Alla'. It was located at Haman-gun and lasted from the first century B.C. until $6^{\text {th }}$ century.

3 Choi Jang-mi, "Haman Sŏngsansansŏng Palguljosa Sŏnggwawa Ch'ult'o Mokki Kŏmto (Results of the excavation and research of Songsan Fortress and a review of the excavated wooden vessels)" (paper presented at the conference <Sŏnsawa Kotae Mokki·Mokkanŭi Ch'oesin Yŏn'gu Hyŏnhwanggwa Kwache (Latest trends and challenges in the research of prehistoric and ancient wooden vessels and wooden tablets) $>$ by the Kaya National Research Institute of Cultural Heritage \& Pokchŏn Museum, Pusan, South Korea, June 24, 2016). 
Tongmunji. Afterward, a total of 314 wooden tablets were discovered in the same place, as well as in the reservoir located west of the East Fortress Wall. Inscriptions made with ink had been left intact on 255 of them. ${ }^{4}$

Studies on wooden tablets excavated at Sŏngsan Fortress began when 27 wooden tablets were showcased in $1998,{ }^{5}$ and an international academic conference with the theme of "The contents and characteristics of wooden tablets excavated from Sǒngsan Fortress in Haman" was held in November 1999. ${ }^{6}$ As the excavation of Sorngsan Fortress continued, the discovery of wooden tablets increased dramatically, and related research became increasingly intensified and diverse. Several scholars have summarized the history of research on wooden tablets and explored the trends and issues surrounding research on these wooden tablets that were pertinent at the time, but it seems that the same issues and challenges remain valid to this day. ${ }^{7}$

4 Choi, "Haman Sŏngsansansŏng Palguljosa Sŏnggwawa Ch'ult'o Mokki Kŏmto." These wooden tablets were introduced in the KCMY, "Report on the excavation of Sŏngsan Fortress" (Vols. I-V), in Han'gukǔi Kodae Mokkan and Han'guk Mokkan Chajǒn. In this study, wooden tablets are referred to by the numbers they were assigned in the Collection of Korean Wooden Tablets, which contains nearly all of the wooden tablets discovered prior to the publication of the fifth report on the excavation of Sŏngsan Fortress. Tablets that have been discovered later have been separately identified.

5 Kungnip Ch'angwŏn Munhwajae Yŏn'guso, Haman Sŏngsansansŏng (Sŏngsan Fortress in Haman) (Ch'angwŏn: KCMY, 1998).

6 The papers presented at this international conference were later published in Han'gukkotaesayŏn'gu (The Journal of Ancient Korean History) 19 (2000).

7 Yi Yonghyŏn (Lee Yong-hyun), “Han'gukkotae Mokkanyŏn'gu (A study of Korea's ancient wooden tablets)" (PhD diss., Korea University, 2001), 101-34; Lee Kyoung-sup, "Haman Sŏngsansansŏng Mokkanŭi Yŏn'gu Hyŏnhwanggwa Kwache (Trends and Prospects of Research on Wooden Tablets from Sŏngsan Fortress in Haman)," Sillamunhwa 23 (2004); Jeon Deog-Jae, "Haman Sŏngsansansŏng Mokkanŭi Yŏn'gu Hyŏnhwanggwa Chaengjŏm (Research Trends and Debates on Wooden Tablets from Haman Sŏngsan Fortress)," Sillamunhwa 31 
Some time has passed since the last study on the history of research on wooden tablets was published, and in the meantime, studies on wooden tablets have expanded in other disciplines, including history, Korean language, and archaeology as well. In addition, the Kaya National Research Institute of Cultural Heritage revealed 23 additional wooden tablets that were discovered in the 17th excavation of Songsan Fortress and is also planning to publish Han'gugŭi Kodaemokkan II: Haman Sŏngsansansŏng (Wooden Tablets of Ancient Korea Vol. 2: Sǒngsan Fortress in Haman) (tentative title), which comprehensively analyzes and compiles all wooden tablets discovered at Sorngsan Fortress up to 2017. ${ }^{8}$ The publication of a book that contains information on all the wooden tablets excavated at Sorngsan Fortress, as well as the official report on the last 23 tablets excavated most recently, could provide an opportunity for another surge in related research on Sǒngsan Fortress wooden tablets. Therefore, while we wait for more studies on Sorngsan Fortress wooden tablets, I believe it is necessary and meaningful to provide an overview of the history of research on wooden tablets to date.

\section{Past and Present Research on Wooden Tablets Excavated from Sǒngsan Fortress in Haman}

In the early phase of research on wooden tablets discovered at Sorngsan

(2008): Lee Kyoung-sup, “Haman Sŏngsansansŏng Ch'ult'o Silla Mokkan Yŏn'guŭi Hŭrŭmgwa Chŏnmang (Research Trends and Prospects of Silla Dynasty Wooden Tablets Excavated from Sŏngsan Fortress in Haman)," Mokkan'gwa Munja (Wooden Documents and Inscriptions Studies) 10 (2013).

8 "Haman Sŏngsansansŏng Ch'ult'o Mokkanesŏ Hwaginhan Yukseki Sillaŭi Yullyŏngch'ekyeawa Silla Wanggyŏnginŭi Kwanjingmyŏng 'Taesa' Tŭng Saeroun Sasil Hwagin (Silla's legal system in the sixth century confirmed by wooden tablets excavated from Sŏngsan Fortress in Haman: newly confirmed part of the legal system and a public post "taesa (大舍)" given to the citizen of the capital city)," Press release from Cultural Heritage Administration, January 4, 2017. 
Fortress, most scholars focused on the external features, such as the form and shape, period of production, use, and the origin of production. After a general consensus on these aspects was reached, scholars began to concentrate on the information contained in the inscriptions, and their interests broadened our understanding of Silla society in the Mid-Ancient Period, particularly concerning the tax collection system, the structure of familial relationships, and the regional government system. In line with the changes in the focus of research on wooden tablets, in this section I hope to trace past research history, starting with studies that explore the external features to the ones that examine the contents of the wooden tablets.

The time frame in which Sorngsan Fortress wooden tablets were produced is generally understood to be the mid-sixth century, around $561 .{ }^{9}$

9 For various perspectives on the period in which wooden tablets were produced, see these aricles. Jeon Deog-Jae, "Haman Sŏngsansansŏng Mokkanŭi Yŏn'gu Hyŏnhwanggwa Chaengjŏm,” 4-5; Lee Sungsi, "Han'guk Mokkanyŏn'guŭi Hyŏnhwanggwa Haman Sŏngsansansŏng Ch'ult'oŭi Mokkan Han'guk Mokkanyŏn'guŭi Hyŏnhwanggwa Haman Sŏngsansansŏng Ch'ult'oŭi Mokkan (Research trends on Korean wooden tablets and wooden tablets excavated from Sŏngsan Fortress in Haman)," Han'gukkodaesayŏn'gu (The Journal of Ancient Korean History) 19 (2000): 104-7; Ju Bo-don, "Haman Sŏngsansansŏng Ch'ult'o Mokkanŭi Kich'ochŏk Kŏmto (A basic review of wooden tablets excavated from Sŏngsan Fortress in Haman)," Han'gukkodaesayŏn'gu 19 (2000): 61-67; Lee Yonghyun, "Haman Sŏngsansansŏng Ch'ult'o Mokkan'gwa Yukseki Sillaŭi Chipanggyŏngyŏng (Wooden tablets excavated from Sŏngsan Fortress in Haman and regional administration in sixth-century Silla)," Tongwŏnhaksul Nonmunjip 5 (2003): 393; Yoon Seon-Tae, "Haman Sŏngsansansŏng Ch'ult'o Silla Mokkanŭi Yongdo (The use of wooden tablets from Silla excavated from Sŏngsan Fortress in Haman)," Chindan Hakpo 88 (1999): 21-2; Yoon Seon-Tae, "Silla Chunggokiŭi Ch'on'gwa To: Ǔmnagi Haech'ewa Kwallyŏnhayŏ [Ch'on (村) and to (徒) in Silla during the sixth and seventh centuries: on the dissolution of Ǔmnak]," Han'gukkodaesayŏn'gu 25 (2002): 148 [In 1999, the wooden tablets were presumed to have been created after the establishment of 'office of tax collection'(Chobu, 調府) in the sixth year in the reign of King Chinp'yŏng (584). This was later revised in the latter article]; Lee Kyoung-sup, "Haman Sŏngsansansŏng Mokkanŭi Yŏn'gu 
There are two main reasons for this conjecture. First, this was the period in which Ara Kaya became part of Silla. Around this time, Silla incorporated Ara Kaya into its kingdom, according to the record from the 22nd year of reign of Emperor Kinmei (561) in the Nihon shōki (The Chronicles of Japan): "Silla built a fortress on P'asa Mountain in Ara." ${ }^{10}$ Since Sorngsan Fortress was built by Silla, scholars generally link the time of its construction to the time Ara Kaya became part of Silla.

Second, local official ranks (oewi, 外位) inscribed on the wooden tablets from Sorngsan Fortress seem to follow the changes in Silla's official ranks around the mid-sixth century as well. The use of “kanji (干支)" as in “sangkanji (上干支)" to mark a particular local official rank, found on the wooden tablets from Sorngsan Fortress, began to change around 561, when the stele to Ch'angnyǒng (Ch'angnyǒngbi) was built, as the last syllable "ji (支)" was dropped to mark the same official rank. Then in 591, the use of "kanji" disappeared completely, as seen on the steles of Namsan Sinsǒng Fortress. Another local official rank, “kŭppŏlch'ǒk (及伐 尺 or 急伐尺)," which was considered to be the lowest ranking office, only appeared on Sǒngsan Fortress wooden tablets, ${ }^{11}$ but recently one scholar proposes that "kóbŏlch'ók (居伐尺)" from the Silla stone momunent in Pongp'yŏng, Uljin, erected in 524 seemed to be a different notation for "kŭppŏlch'ŏk." According to this theory, the official rank of kŭppŏlch'ŏk disappeared between the reigns of King Chinhŭng and King Chinp'yŏng,

Hyŏnhwanggwa Kwache," 218; Lee Kyoung-sup, "Sŏngsansansŏng Ch'ult'o Hach'al Mokkanŭi Chejakchiwa Kinŭng [The origin of production and use of wooden tablet labels (hach'al mokkan) excavated from Sŏngsan Fortress]," Han'gukkodaesayŏn'gu 37 (2005): 143-6.

10 Kim Tae-Sik, "Haman Annakukŭi Sŏngjanggwa Pyŏnch'ŏn (The growth and transformation of Ara Kaya in Haman)," Han'guksayŏn'gu (The Journal of Korean History) 86 (1998): 67-8; Nam Jae Woo, Allakuksa (History of Ara Kaya) (Seoul: Hyean, 2003), 292-7.

11 Yoon Seon-Tae, "Haman Sŏngsansansŏng Ch'ult'o Silla Hach'alŭi Chaekŏmto (Revisiting Silla's labels (hach'al) excavated from Sŏngan Fortress in Haman)," Sarim 41 (2012): 163-4. 
as the rank does not appear on the steles of Namsan Sinsǒng Fortress erected in 591, which is known to contain the most amount of information on Silla's official ranks. ${ }^{12}$

Recently, however, another scholar speculates that the foundation for Songsan Fortress was first laid in the mid-seventh century, based on the wooden tablets and a small bowl excavated from the leaf-paved layer of the fortress. ${ }^{13}$ Other scholars have also stated their views on the time frame of the establishment of the Sorngsan Fortress, some claiming that the foundation for the fortress was laid in the mid-sixth century based on the evidence found in the leaf-paved layer, the first pit dwelling site within the fortress, and earthenware excavated from stone-filled drains, while arguing that the reconstruction of the East Fortress Wall, where the leafpaved layer was laid, began in the early seventh century. ${ }^{14}$ Although these archaeological theories differ on the time frame of when the foundation for the fortress was first laid, they agree on the fact that the wooden tablets excavated from the leaf-paved layer were produced in the early seventh century at the latest. Moreover, another scholar calculates the "Imja year (壬子年)" mentioned on the recently-released tablet No. 22 from the 17 th excavation of Sorngsan Fortress as the year 592, based on the above theories deduced from the small bowl discovered in stone-filled drains. The same scholar speculates that the Sorngsan Fortress wooden tablets were created for the establishment of a fortress and reservoir and the increase of military power in order to prepare for the possible Japanese in-

12 Yoon Seon-Tae, "Sillaŭi Ch'oki Oewich'ekyewa 'Kŭppŏlch'ŏk' (Local government posts system in early Silla and kŭppŏlch'ŏk)," Tongguk Sahak 61 (2016): 167-72.

13 Lee Ju-Heun, "Haman Sŏngsansansŏng Puyŏpch'unggwa Ch’ultoyumurŭi Kŭmto (An Examination of the Leaf-paved Layer and Excavated Relics from Haman Sŏngsan Fortress)," Chunganggokoyŏn'gu (Journal of the Central Institute of Cultural Heritage) 16 (2015): 91-9.

14 Yoon Sang-deok, "Haman Sŏngsansansŏng Ch'ucho Yŏndaee Kwanhayŏ (A Consideration on the Construction Date of Seongsan Sanseong Fortress in Haman)," Mokkan'gwa Munja (Wooden Documents and Inscriptions Studies) 14 (2015). 
vasion after the Battle of Amaksǒng in $602 .{ }^{15}$

Yet, another scholar presents a counterargument. He argues that the shape and form of small bowls like the one found in the drain did not change much to provide the grounds for deducing specific chronology, ${ }^{16}$ and a large number of wooden tablets had already been buried to strengthen the ground beneath the fortress walls as part of the foundation for the East Fortress Wall. ${ }^{17}$ Regarding the inscription on wooden tablet No. 21 from the seventeenth excavation of Sorngsan Fortress (17-No. 21), the Chinese characters found on the tablet were assumed to be “王子寧” when it was first revealed earlier this year, but soon others objected, claiming it was “壬子年.” The latter gained more strength through an analysis of the inscriptions performed using the Japanese computer program for decoding calligraphy on wooden tablets. ${ }^{18}$ If the characters are confirmed to be “壬子年,” this tablet would be the first one with the mention of a year in the sexagenary cycle. It certainly is a notable perspective, but as seen in the case of the Chungsongni stele, the mention of a year in the sexagenary cycle does provide the grounds for confirming the period in which the wooden tablets were created. Moreover, it diverges from the general format of other wooden tablets from Sŏngsan Fortress, which means that it is possible for those characters to be part of a place name,

15 Son Hwan Il, "Haman Sŏngsansansŏng Ch'ult'o Mokkanŭi Ǔimiwa Sŏch’e (The meaning and typography of wooden tablets excavated from Sŏngsan Fortress in Haman-gun)," Han'guksahaksahakpo (The Korean History Journal of Historiography) 35 (2017): 16-21. Hereafter, wooden tablets discovered in the seventeenth excavation of Sŏngsan Fortress will be identified according to the numbering system used in this article (E.g. "17-No. 1," "17-No. 2," etc.).

16 Yoon Sang-deok, "Haman Sŏngsansansŏng Ch’ucho Yŏndaee Kwanhayŏ,” 84.

17 Yoon Seon-Tae, "Han'guk Kotae Mokkanŭi Yŏn'guhyŏnhwanggwa Kwaje (Research and perspectives on the wooden documents of ancient Korea)," Sillasahakpo 38 (2016): 397.

18 “王子寧” on a Sŏngsan Fortress wooden tablet should be read as ‘壬子年', The Dong-a Ilbo, March 6, 2017; "The production period of Sŏngsan Fortress wooden tablets confirmed using a computer program, changing the earlier interpretation of ancient Korean history,” The Dong-a Ilbo, July 11, 2017. 
and it is also possible that the writings on these tablets were not necessarily created in the imja year. Therefore, it would be of great importance to take these theories into consideration and review the format and other external aspects related to 17-No. 21. In addition, as mentioned above, 17-No. 21 exhibits characteristics specific to the mid-sixth century, which requires a more studied approach for the analysis of the inscriptions in the future.

Concerning the use of wooden tablets, in the early research phase, the characters “稗," “稗一,” and “稗石” written on the tablets were considered to be a different notation for “彼日 (p'iil), ” the tenth rank in the Silla dynasty's local official rank system. As a result, they were considered to be nameplates used to keep record of the people who participated in the construction of the fortress. ${ }^{19}$ However, soon another theory was proposed, arguing that these wooden tablets were labels attached to the items offered to the king, since the content and format of the tablets seemed to resemble Japan's labels (J. nifuda, 荷札), and the “稗” on the tablets could be read as $p$ ' $i$, or millet. ${ }^{20}$ This theory has gained a lot of support.

19 Kim Chang Ho, "Haman Sŏngsansansŏng Ch'ult'o Mokkane Taehayŏ (On the wooden tablets excavated from Haman Sŏngsan Fortress)," in Haman Sŏngsansansŏng (Sŏngsan Fortress of Haman), ed. Kungnip Ch'angwŏn Munhwajae Yŏn'guso (Ch'angwŏn: KCMY, 1998), 92; Ju Bo-don, "Haman Sŏngsansansŏng Ch'ult'o Mokkanŭi Kich'ochŏk Kŏmto," 58; Xie Guihua, "Chunggugesŏ Ch'ult'odoen Wijindae Ihuŭi Hanmun'kanjimunsŏwa Sŏngsansansŏng Ch'ult'o Mokkan (Chinese documents from the Wei and Jin dynasties found in China and wooden tablets discovered in Sŏngsan Fortress)," Han'gukkodaesayŏn'gu (The Journal of Ancient Korean History) 19 (2000): 203; Park Jong Ik, "Haman Sŏngsansansŏng Palguljosawa Mokkan (Wooden tablets and excavation of Sŏngsan Fortress in Haman)," Han'gukkodaesayŏn'gu 19 (2000): 25; Park Jong Ik, "Haman Sŏngsansansŏng Ch'ult'o Mokkanŭi Sŏnggyŏk Kŏmt'o (A review of the characteristics of wooden tablets excavated from Sŏngsan Fortress in Haman)," Han'gukkogohakpo (Journal of the Korean Archaeological Society) 48 (2002).

20 Hirakawa Minami, “Ilbon'godaemokkan Yŏn'guŭi Hyŏnhwanggwa Sinsijŏm (Current trends and new implications of research on ancient Japanese wooden tablets)," Han'gukkodaesayŏn'gu 19 (2000). 
Others further speculate that the tablets included both labels and nameplates, depending on their content and format. ${ }^{21}$

The use of these wooden tablets became clear as more and more of them were discovered. Most of the Songsan Fortress wooden tablets contained the following information in this order: place name, person's name, item, and number of items. At times, the name and number of items were excluded. ${ }^{22}$ On the bottom, the tablets were marked with a hole or a vshaped groove, and some still had twine attached. Considering the form and the format of the content of the tablets, it seems that most of the Songsan Fortress wooden tablets were labels, with the exception of a few that could be categorized as some form of a document or other records. ${ }^{23}$

The place names on these wooden tablets, such as Kuribǒl, Kot'a, Kŭppǒlsǒng, and Kammunsǒng, were regions under the jurisdiction of Sangju according to the "Chiriji (Treatise on geography, 地理志)" in the Samguksagi (History of The Three Kingdoms, 三國史記), or the pres ent-day northern region of North Kyŏngsang Province. As this region was located along the Nakdong River system, the place names confirmed that Silla administered or governed the areas that used to be part of Old Kaya and also collected taxes from those regions through the waterways

21 Yoon Seon-Tae, "Haman Sŏngsansansŏng Ch'ult'o Silla Mokkanŭi Yongdo," 1420; Yoon Seon-Tae, "Silla Chunggokiŭi Ch'on'gwa To: Ǔmnagi Haech'ewa Kwallyŏnhayŏ," 150-3; Kim Jae Hong, "Haman Sŏngsansansŏng Ch'ult'o Mokkan'gwa Ch'ollaksahoeŭi Pyŏnhwa (Wooden tablets from Sŏngsan Fortress in Haman and the changes in local societies)," Kuksagwannonch'ong (Treatises on Korean history) 106 (2005).

22 Lee Kyoung-sup, “Sŏngsansansŏng Ch'ult'o Silla Chimkkorip'yo(荷札) Mokkanŭi Chimyŏng Munjewa Chejak Tanwi (The issue of toponymy found on wooden labels from Silla excavated from Sŏngsan Fortress)," Sillasahakpo 23 (2011): 559.

23 Lee Yong-hyun, "Haman Sŏngsansansŏng Ch'ult'o Mokkanŭi Sŏnggyŏngnon: 2ch'a Pogobunŭl Chungsimŭro (A theory on the characteristics of wooden tablets excavated from Sŏngsan Fortress in Haman: a review of the second excavation report)," Kogohakji 14 (2005); Lee, Kyoung-sup. "Sŏngsansansŏng Ch'ult'o Hach'al Mokkanŭi Chejakchiwa Kinŭng." 
of the Nakdong River and brought them together at Haman. ${ }^{24}$

There also have been two diverging opinions regarding the chracateristics of ch'on (villages, 村) even prior to the discovery of wooden tablets at Sorngsan Fortress, with some claiming that they were "natural villages" (chayŏnch'on), which were spontaneously formed settlements, while others argued that they were "administrative villages" (haengjŏngch'on), formed by the government for administrative purposes. The discovery of the Sǒngsan Fortress wooden tablets reignited this debate over the characteristic and structure of the villages, as multiple place names, such as "Kuribŏl-Sangsamjach'on" and "Kot'a-Milch'on" were found on a single tablet. $^{25}$ In addition, these labels with village names made it possible to confirm that natural villages were the basic unit of tax collection in the sixth century.

A closer look at the place names on wooden tablets also reveals that some tablets contained the words “ponp'a (本波)," “ana (阿那),” “malna (末那),” and “chŏnna (前那),” which were mostly found between the name of a natural village and a person's name, as in “古阤伊骨利村阿那奐智卜 利古支/稗發” (Chajǒn-No. 28), or between an administrative village name and a natural village name, as in “鄒文前那牟只村/伊[利]習” (Chajǒn-No. 177). The first time the above words were discovered, scholars debated whether to understand them as spatial concepts or as official titles. In the case of spatial concepts, people focused on the meaning of the character “本” from "ponp'a (本波)" and speculated that these were the names of villages or regions before they became administrative villages, and "ana (阿那)" were understood as settlements located in the riverside plains. ${ }^{26}$

24 Yoon Seon-Tae, "Haman Sŏngsansansŏng Ch'ult'o Silla Mokkanŭi Yongdo," 20; Lee Yong-hyun, "Haman Sŏngsansansŏng Ch'ult'o Mokkan'gwa Yukseki Sillaŭi Chipanggyŏngyŏng," 58-60; Lee, Kyoung-sup. "Sŏngsansansŏng Ch'ult'o Silla Chimkkorip'yo Mokkanŭi Chimyŏng Munjewa Chejak Tanwi," 539-46.

25 For various perpsectives on the nature of ch'on seen on Sŏngsan Fortress wooden tablets, see Jeon Deog-Jae, "Haman Sŏngsansansŏng Mokkanŭi Yŏn'gu Hyŏnhwanggwa Chaengjŏm,” 15-7.

26 Jeon Deog-Jae, "Haman Sŏngsansansŏng Mokkanŭi Naeyonggwa Chunggogi 
Others took note of the words "sent millet (稗發)" on Chajón- No. 28 and hypothesized that the words “ponp'a (本波)" and “ana (阿那)" referred to the person in charge of transporting grains. ${ }^{27}$ Then, “chǒnna (前那)" was found on the later discovery Chajón-No. 177, which strengthened the theory that these words were spatial concepts. According to this theory, the words “ponp’a (本波),” “ana (阿那),” “malna (末那),” and “chŏnna (前 那)" appeared with place names on the wooden tablets, and therefore indicated directions. Specifically, they were believed to be equivalent to the cardinal points of direction used in Koguryŏ and Paekche: "chŏnna (前 那)” was south; “malna (末那),” north; “ana (阿那),” west; and “ponp’a (本波)," center. And the corresponding regions were understood as places with advanced government administration, created in the process of expansion and structural stratification of settlements. ${ }^{28}$

In the early phase of research, scholars also believed that the wooden tablets were created at Sŏngsan Fortress, since they were assumed to be nameplates. ${ }^{29}$ However, the general consensus today is that they were created in the first of the two area names marked on the tablets, such as Kuribŏl (仇利伐), Kot'a (古阤), or Kubŏl (仇伐). There are varying opinions regarding the level of production, depending on the perspectives on the structure of villages. Through an analysis of the format and handwrit-

Sillaŭi Such'wich'egye (Contents of wooden tablets found at Sŏngsan Fortress in Haman and the tax collection system in Silla in the mid-ancient period)," Yǒksawa Hyŏnsil 65 (2007): 224-32; Kwon In-han, "Kodae Chimyŏnghyŏngt'aeso 'ponp'a/ponp'i'e Taehayŏ [On the morphemes 'ponp'a/ponp'i (本波/本彼)' in ancient place names]," Mokkan'gwa Munja (Wooden Documents and Inscriptions Studies) 2 (2008).

27 Lee Su Hun, “Sŏngsansansŏng Mokkanŭi 'Ponp'a’wa 'Malna’‘Ana' (‘本波,' ‘末 那,' and ‘阿那’ in wooden tablets of Sŏngsan Fortress),” Yǒksawa Segye (History and the World) 38 (2010): 129-38.

28 Lee Kyoung-sup, "Sŏngsansansŏng Ch'ult'o Silla Chimkkorip'yo Mokkanŭi Chimyŏng Munjewa Chejak Tanwi," 546-7.

29 Park Jong Ik, "Haman Sŏngsansansŏng Palguljosawa Mokkan”; "Haman Sŏngsansansŏng Ch'ult'o Mokkanŭi Sŏnggyŏk Kŏmt'o.” 
ing on the tablets, some who believe that villages were created for administrative purposes propose that multiple scribes on the kun (county, 郡) level filled out the wooden tablets. ${ }^{30}$ Prior to this theory, other scholars who believed in spontaneously formed natural villages had suggested that the tablets were created on the administrative village level, as the format and form of the tablets displayed distinct local characteristics. ${ }^{31}$ Recently, others have expanded on this theory and, focusing on natural villages as the basic unit of tax collection, assert that the wooden tablets were also created on the natural village level. ${ }^{32}$

Local official ranks and the term “noin (奴人)” were two characteristics found on the wooden tablets in relation to people's names. The types of official ranks and their understanding were discussed earlier in this paper, related to the production period of wooden tablets, and therefore will not be discussed further in this section. Instead, I would like to examine the use of the term "noin." On Sorngsan Fortress wooden tablets, "noin" often

30 Hashimoto Shigeru, “城山山城木簡と六世紀新羅の地方支配 (Wooden tablets from Sŏngsan Fortress and Silla's regional ruling system in the sixth century)," in 東ア ジア古代出土文字資料の研究 (A study on the excavated historical documents and records of ancient East Asia), ed. Kudo Modoo \& Lee Sungsi (Tokyo: Yuzankaku, 2009), 288-301. The author of this study also provides a comparative analysis of the labor mobilization system and document administration found on Sŏngsan Fortress wooden tablets, Myŏnghwal Fortress stele, and Namsan Sinsŏng steles. The results of this study will be discussed in detail in the next section.

31 Jeon Deog-Jae, "Haman Sŏngsansansŏng Mokkanŭi Naeyonggwa Chunggogi Sillaŭi Such'wich'egye," 232-40; Jeon Deog-Jae, "Haman Sŏngsansansŏng Ch'ult'o Silla Hach'almokkanŭi Hyŏngt'aewa Chejakchiŭi Kŏmt'o (The form and places of production of wooden tablet labels excavated from Sŏngsan Fortress in Haman)," Mokkan'gwa Munja (Wooden Documents and Inscriptions Studies) 3 (2009): 7382; Lee Kyoung-sup, "Sŏngsansansŏng Ch'ult'o Silla Chimkkorip'yo Mokkanŭi Chimyŏng Munjewa Chejak Tanwi," 557-73.

32 Kim Chang-seok, "Haman Sŏngsansansŏng Mokkanŭl T'onghae Pon Sillaŭi Chibangsahoe Kujowa Such'wi (The structure of regional societies and the tax collection system of Silla according to the wooden tablets from Sŏngsan Fortress in Haman)," Paekchemunhwa 54 (2016): 167-9. 
appeared between the names of people, usually in the following format: “place name, person A, noin 奴(人), person B, $p u$ (負).” Various speculations have been made regarding the status and role of noin.

Table 1. The Inscription of "Noin (奴人)” on Wooden tablets from Sǒngsan Fortress in Haman

\begin{tabular}{|c|c|c|c|c|c|}
\hline & Place & + Person A & + 奴(人) & + Person B & + 負 \\
\hline Chajŏn-No. 26 & $\begin{array}{c}\text { 仇利伐 } \\
\text { (Kuribǒl) }\end{array}$ & $\begin{array}{c}\square \text { 德知一伐 } \\
\text { ( } \square \text { tǒkji ilbŏl) }\end{array}$ & $\begin{array}{l}\text { 奴人 } \\
\text { (noin) }\end{array}$ & $\square$ & \\
\hline Chajŏn-No. 35 & & $\begin{array}{c}\text { 內恩知 } \\
\text { (Naeŭnji) }\end{array}$ & $\begin{array}{l}\text { 奴人 } \\
\text { (noin) }\end{array}$ & $\begin{array}{l}\text { 居助支 } \\
\text { (Kŏjoji) }\end{array}$ & $\begin{array}{l}\text { 負 } \\
(\mathrm{pu})\end{array}$ \\
\hline Chajŏn-No. 36 & $\begin{array}{c}\text { 仇利伐 } \\
\text { (Kuribǒl) }\end{array}$ & $\begin{array}{c}\text { 只師智 } \\
\text { (Chijŭkji) }\end{array}$ & $\begin{array}{l}\text { 奴 } \\
\text { (no) }\end{array}$ & $\begin{array}{l}\text { 於非支 } \\
\text { (OObiji) }\end{array}$ & $\begin{array}{c}\text { 負 } \\
(\mathrm{pu})\end{array}$ \\
\hline Chajŏn-No. 38 & & $\begin{array}{l}\text { 比夕智 } \\
\text { (Pisǒkji) }\end{array}$ & $\begin{array}{l}\text { 奴 } \\
\text { (no) }\end{array}$ & $\begin{array}{l}\text { 余先能支 } \\
\text { (Isǒnnŭngji) }\end{array}$ & $\begin{array}{c}\text { 負 } \\
(\mathrm{pu})\end{array}$ \\
\hline Chajŏn-No. 156 & $\begin{array}{l}\text { 仇利伐仇阤 } \\
\text { (Kuribǒlgut’a) }\end{array}$ & $\begin{array}{c}\text { 知一伐 } \\
\text { (Chi ilbŏl) }\end{array}$ & $\begin{array}{l}\text { 奴人 } \\
\text { (noin) }\end{array}$ & $\begin{array}{l}\text { 毛利支 } \\
\text { (Moliji) }\end{array}$ & $\begin{array}{l}\text { 負 } \\
(\mathrm{pu})\end{array}$ \\
\hline
\end{tabular}

Prior to the excavation of wooden tablets at Sorngsan Fortress, the existence of “noin" and “noinbŏp (奴人法, noin law)" were confirmed by the Silla stone momunent in Pongp'yŏng, Uljin, and spurred research to clarify the nature of the terms. Although there were differences in terms of the specifics, generally noin were understood to be the people of border regions that were incorporated into Silla, whose positions were inferior to those of the people of Silla. In this context, an earlier study, which deciphered the term noin from the inscriptions on the Sorngsan Fortress wooden tablets, read the last character on Chajŏn-No. 26 as “塩 (salt)" and construed that the inscription on the wooden tablet was " $\square$ tŏkji ilbŏl, residing in Kuribŏl, is a noin; offered salt to the throne." This interpretation of the inscription was premised on the following understanding: 1) noin were a group of subjugated people; 2) $\square$ torkji was the head of a noin village with the official position of ilbŏl (一伐); and 3) this noin village 
sent salt to the throne. ${ }^{33}$

The discovery of additional wooden tablets with the inscription noin enabled further discussions regarding the specific status, position, and role of noin. In this process, the character “負 (pu)" came to particular attention, as it commonly appeared after the term noin and a person's name. One scholar proposes that it signified "goods," referring to items set apart to be moved or sent to a different place, ${ }^{34}$ but a more common interpretation is that it was a verb, referring to a transportation method, meaning "carried on the back." 35

However, the excavation of Chajŏn-No. 219 provides a new understanding of “負 (pu)." The inscription on the back side of Chajŏn-No. 219 was read as “此負刀寧負盜人有,” meaning “these goods (負) are the young master's goods (負); it had been stolen,” and reinforced the idea that "pu" was a noun, referring to "goods." This discovery has also led to the understanding that the character “發 (pal)," which was used in a similar manner as “負 (pu)," was interchangeable with pu. Pal was considered to be the $i d u$ notation of "pari," a type of goods collected as tax. ${ }^{36}$

With the increase in the number of additional wooden tablets, the discussion on noin has evolved as well. Since the term noin appeared between the names of people, opinions vary regarding whether to apply the

33 Lee Sungsi, "Han'guk Mokkanyŏn'guŭi Hyŏnhwanggwa Haman Sŏngsansansŏng Ch'ult'oŭi Mokkan," 99-104.

34 Lee Su Hun, "Haman Sŏngsansansŏng Ch'ult'o Mokkanŭi Pisŏkkwa Pu [P'isŏk (稗 石) and $\mathrm{Pu}$ (負) on wooden tablets excavated from Sŏngsan Fortress in Haman]," Chiyŏkkwa Yŏksa 15 (2004): 31-2.

35 Jeon Deog-Jae, "Haman Sŏngsansansŏng Mokkanŭi Naeyonggwa Chunggogi Sillaŭi Such'wich'egye," 245; Kim Chang-seok. "Silla Chunggogiŭi Noin'gwa Nobi: Sŏngsansansŏng Mokkan'gwa 'Pongp'yŏngbi'ŭi Punsŏgŭl Chungsimŭro [Silla's noin (奴人) and nobi (奴婢) in the mid-ancient period: based on the analysis of wooden tablets found at Sŏngsan Fortress in Haman and the Silla stele in Pongp'yŏng]," Han'gukkodaesayŏn'gu (The Journal of Ancient Korean History) 54 (2009): 53-5.

36 Yoon Seon-Tae, "Haman Sŏngsansansŏng Ch'ult'o Silla Hach'alŭi Chaekŏmto," 164-6. 
term to the first person (A) or the second person (B). The general understanding seems to be that it is attached to person B, meaning "A's noin B. ${ }^{37}$ Regarding the status of noin, some argue that they were groups of people subjugated by Silla, ${ }^{38}$ based on the concept of noin and noin village mentioned on the Silla stone momunent in Pongp'yŏng, Uljin; others speculate that they were subjugated people who were in the process of becoming freemen under a voluntary servitude system $^{39}$; still others hypothesize that they were commoners engaged in menial labor (shillyang yŏkch'on，身良役賤). ${ }^{40}$ Currently, the general understanding of noin seems to be that the term refers to private slaves, considering the format of inscriptions: "A's noin B." ${ }^{41}$ However, there are differences in opinions regarding the role of noin even among those who believed that noin were private slaves. Some argue that private slaves were not taxed and therefore interpret “負 (pu)" as "carried on the back," so that the inscrip-

37 Lee Su Hun, "Haman Sŏngsansansŏng Ch'ult'o Mokkanŭi Pisŏkkwa Pu," 34-5; Jeon Deog-Jae, "Haman Sŏngsansansŏng Mokkanŭi Naeyonggwa Chunggogi Sillaŭi Such'wich'egye," 242-3; Yoon Seon-Tae, "Haman Sŏngsansansŏng Ch'ult'o Silla Hach'alŭi Chaekŏmto," 167-8.

38 Lee Yong-hyun, "Haman Sŏngsansansŏng Ch'ult'o Mokkan (Wooden tablets excavated from Sŏngsan Fortress in Haman.)," in Han'gugŭi Kodaemokkan (Wooden tablets of Ancient Korea), ed. Kungnip Ch'angwŏn Munhwajae Yŏn'guso (Ch'angwŏn: KCMY, 2004), 376; Park Jong-ki, "Han'guk Kodaeŭi Noin'gwa Pugok [Noin (奴人) and Pugok (部曲) in ancient Korea],” Han'gukkodaesayŏn'gu (The Journal of Ancient Korean History) 43 (2006): 46-74.

39 Lee Kyoung-sup, "Sillaŭi Noin (Silla's noin)," Han'gukkodaesayŏn'gu (The Journal of Ancient Korean History) 68 (2012).

40 Lee Su Hun, "6segi Silla Noinŭi Sŏnggyŏk (The nature of noin in sixth century Silla)," Han'gungminjongmunhwa (Journal of Koreanology) 52 (2014): 49-51.

41 Yoon Seon-Tae, "Haman Sŏngsansansŏng Ch'ult'o Silla Mokkanŭi Yongdo," 16; Lee Su Hun, "Haman Sŏngsansansŏng Ch'ult'o Mokkanŭi Pisŏkkwa Pu," 35-6; Jeon Deog-Jae, "Haman Sŏngsansansŏng Mokkanŭi Naeyonggwa Chunggogi Sillaŭi Such'wich'egye,” 243. 
tion described a private slave transporting the taxes of his owner. ${ }^{42}$ Others argue that, as in ancient China, private slaves were also taxed in Silla, and interpret “負 (pu)" as "goods" the slaves were paying as taxes. ${ }^{43}$

All mentions of noin on wooden tablets from Sŏngsan Fortress were found with the place name “Kuribŏl (仇利伐)." Emphasizing the presence of noin, some speculate that Kuribŏl was a noin village. ${ }^{44}$ However, as the names on wooden tablets include those who were not noin, the general consensus seems to be that noin resided in the same village as commoners. $^{45}$ In light of new studies on noin, now scholars are redefining the characteristics of noin and noin villages in consideration of both the wooden tablets and the Silla stone momunent in Pongp'yŏng. ${ }^{46}$

In this section, I have reviewed and summarized the studies that discuss the time period in which the Sŏngsan Fortress wooden tablets were created, their use, as well as place names, official ranks, noin and other inscriptions marked on the wooden tablets. This study focuses particularly on the research papers published after the last study that summarizes the history of research on the Sŏngsan Fortress wooden tablets was compiled. Unfortunately, it is not possible in this paper to discuss a few other topics, and detailed descriptions and differences in perspectives can be found in

42 Jeon Deog-Jae, "Haman Sŏngsansansŏng Mokkanŭi Naeyonggwa Chunggogi Sillaŭi Such'wich'egye,” 243-5. Lee Su Hun, "6segi Silla Noinŭi Sŏnggyŏk (The nature of noin in sixth century Silla)," 48-9. Lee Su Hun understood noin as people who were involved in the transportation of goods, although he did not consider noin to be private slaves.

43 Yoon Seon-Tae, "Haman Sŏngsansansŏng Ch'ult'o Silla Hach'alŭi," 169-70.

44 Lee Yong-hyun, "Haman Sŏngsansansŏng Ch'ult'o Mokkan,” 376.

45 Lee Su Hun, "Haman Sŏngsansansŏng Ch'ult'o Mokkanŭi Pisŏkkwa Pu," 35-6; Lee Kyoung-sup, "Sillaŭi Noin,” 206-11; Noh Choong Kook, "Sillaŭi Noinch'on: 'Uljinbongp'yŏngsillabi'rŭl Chungsimŭro [Silla's noinch'on (noin village): Silla stele in Pongp'yŏng, Uljin]," Taegusahak (The Taegu Historical Review) 125 (2016): 10.

46 Park Jong-ki, "Han'guk Kodaeŭi Noin'gwa Pugok"; Kim Chang-seok, "Silla Chunggogiŭi Noin'gwa Nobi”; Lee Kyoung-sup, "Sillaŭi Noin”; Lee Su Hun, "6segi Silla Noinŭi Sŏnggyŏk"; Noh Choong Kook, "Sillaŭi Noinch'on." 
previously published studies on the history of research on Songsan Fortress wooden tablets. The research introduced in this section of the study were mainly focused on labels, which accounted for most of the wooden tablets found at Sŏngsan Fortress. In the following section, I would like to discuss the wooden tablet documents (munsŏ mokkan).

\section{Information on Laws and the Labor Mobilization System Gleaned from Wooden Tablet Documents}

Research on wooden tablets excavated from Sŏngsan Fortress has been focused on wooden tablet labels (hach'al mokkan), which account for an overwhelming majority. The heightened interest and research on the labels seem natural, considering the extensive number of the tablets and information contained in them. Other wooden tablets, such as wooden tablet documents (munsŏ mokkan) have been neglected by comparison. A few recent studies, however, examine and discuss these non-label tablets. One paper examines Chajŏn-No. 218 and finds it to be a note attached to a liquor jar, which could offer insight into the daily lives of the people at the time. In addition, three four-sided wooden tablets were discovered: Chajŏn-No. 127, Chajŏn-No. 221, and Chajŏn-No. 223. Among them, Chajön-No. 127 was presumed to be a document that recorded the number of laborers taken from each village for the construction of the fortress as well as the increase and decrease of their numbers. ${ }^{47}$ Inscriptions made in ink were found on all four sides of Chajŏn-No. 221 and Chajŏn-No. 223 , and as a result the two wooden tablets were believed to be document tablets. With the resources released to date, the inscriptions have been difficult to decipher. But recently, a new study was published, offering a new way to decipher and interpret the inscriptions on Chajŏn-No. 221 from the perspective of Korean literature, spurring a new perspective and

47 Yoon Seon-Tae, "Haman Sŏngsansansŏng Ch'ult'o Silla Hach'alŭi Chaekŏmto," $163-4$. 
discussion. $^{48}$

In addition, one four-sided wooden tablet was included in the wooden tablets discovered in the seventeenth excavation campaign and recently released to the public. This four-sided wooden tablet, designated 17-No. 1, contained inscriptions on all four sides. From the content of the writings, the wooden tablet seems to be a document. A press release as well as two studies have dealt with the dechipering and interpretation of the inscriptions on 17-No. $1,{ }^{49}$ which are described in the following:
Figure 1. Haman Sŏngsan Fortress wooden tablet 17No. 1

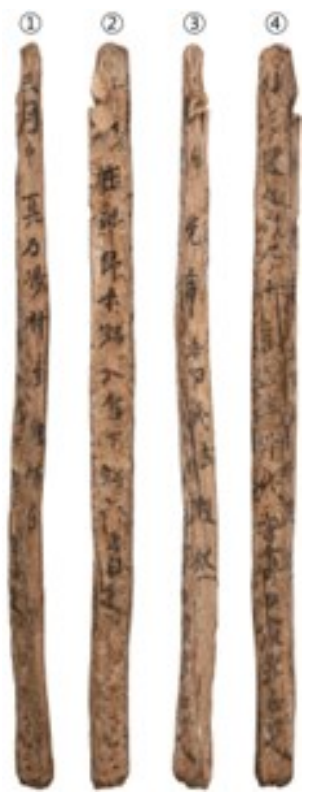

48 Lee Seung-jae, "Haman Sŏngsansansŏng 221ho Mokkanŭi Haedok (Decoding the inscriptions on wooden tablet No. 221 from Sŏngsan Fortress in Haman)," Han'gungmunhwa (Korean culture) 61 (2013); Lee Young-hyun, "Haman Sŏngsansansŏng Ch'ult'o Mokkan 221hoŭi Kugŏhakchŏk Ǔiǔi (The linguistic significance of wooden tablet No. 221 excavated from Sŏngsan Fortress in Haman)," Kugyŏryŏn'gu (Kugyol Studies) 34 (2015).

49 Press release from Cultural Heritage Administration, January 4, 2017; Son Hwan Il, "Haman Sŏngsansansŏng Ch'ult'o Mokkanŭi Ǔimiwa Sŏch'e," 11-4; Kim Changseok, "Haman Sŏngsansansŏng 17ch'a Palguljosa Ch'ult'o Samyŏnmokkan (23pŏn)e Kwanhan Sigo [A study on the four-sided wooden tablet (No. 23) discovered in the seventeenth excavation of Sŏngsan Fortress in Haman]," Han'guksayŏn'gu (The Journal of Korean History) 177 (2017): 126-39. 
$[\text { [nscription }]^{50}$

(1) 三月中眞乃滅村主憹怖白

(2) 口城在弥節尔智大舍下智前去白之

(3) 即白先蓈卒日代法稚然

（4) 伊汑罹及伐尺实言迴法卅代告今卅日食去白之

[Interpretation]

(1) In March, I, the leader of Chinnaemyŏl village, report this in fear.

(2) I report to Mijŭkiji taesa (大舍, 12th of the 17 official ranks) haji (下 智) in $\square$ fortress ( $\square$ 城).

(3) I report that I had been foolish, because previously the law (代法) stated 60 days.

(4) It'angni (伊汑罹) Kŭppŏlch'ŏk (及伐尺, an official rank) sidestepped the law and said 30 days, and now he is gone after 30 days.

Since the ink inscriptions on 17-No. 1 were generally clear, there was not much to dispute regarding its content. However, scholars propose different views regarding the details of the content and the recipient of the wooden tablet document. The common understanding was that this was a report filed by the leader of Chinnaemyŏl village regarding the error he made in administering the law, and that It'angni Kŭppŏlch'ŏk only served 30 days instead of the full 60 days. Instead of delving into the deciphered

50 The following are characters that are currently under debate: (there are three different opinions - press release from the Cultural Heritage Administration, hereafter CHA; Son Hwan-il, "Son"; and Kim Ch'ang-sŏk, "Kim")

(2)-1: $\square$ (CHA, Kim) 此 (Son)

(2)-6: 尔 (CHA, Son) 等 (Kim)

(4)-2: 他 (CHA, Son) 汑 (Kim)

(4)-7: 寀 (CHA, Son) 莱 (Kim)

(4)-9: $\square$ (CHA) 廻 (Kim, Son) 
and interpreted inscriptions on 17-No. 1, let us concentrate on new information about mid-sixth century Silla on this wooden tablet.

First, what kind of legal terms were the "60-day taeböp (六日代法)” or the “hoеро̆p 30 days" (迴法卅代)" mentioned on the wooden tablet? The term "substitution law (taebŏp, 代法)" following "60 days" does not appear in existing historical documents or epigraphs. However, considering the meaning of “代 (tae)," which is "to substitute" or "to replace" and the context of the inscriptions on 17-No. 1, it can be understood as one of the following: a law that stipulated one to perform labor in lieu of another person; a law that stipulated one to perform labor in lieu of paying one's taxes; or a law that stipulated a rotational shift system for statute labor. As for “hоерор 30 days," hоеро̆р (迴法) does not seem to be a kind of law like taepop and could be understood as "avoiding the law." the substitution law becomes relevant to "hoepŏp thirty days." Chajŏn-No. 221 , one of the wooden tablets discovered earlier, offers a hint regarding this term. The inscriptions and interpretations on Chajŏn-No. 221 can be understood as follows: ${ }^{52}$

[Inscription]

Chajŏn-No. 221 (1) 六月中 $\square$ 预 $\square$ 城 $\square$ 邦村主敬白之 $\square \square \square$ 成行之

Chajŏn-No. 221 (2) 㝸巾來昏 $\square \square$ 也爲六 $\square$ 大城從人丁交日

Chajŏn-No. 221 (3) $\square \square$ 走 $\square$ 日來 $\square \square \square$ 更 $\square$ 有干 $\square$

Chajŏn-No. 221 (4) 卒日治之人此人烏 $\square$ 城置不行遣乙白

51 Kim Chang-seok, "Haman Sŏngsansansŏng 17ch'a Palguljosa Ch'ult'o Samyŏnmokkan (23pŏn)e Kwanhan Sigo,” 140.

52 The inscriptions of this wooden tablet were deciphered and interpreted in the following papers. Son Hwan Il, Han'guk Mokkan Chajŏn; Lee Seung-jae, "Haman Sŏngsansansŏng 221ho Mokkanŭi Haedok"; Lee Yong-hyun, "Haman Sŏngsansansŏng Ch'ult'o Mokkan 221hoŭi Kugŏhakchŏk Ǔiŭi." The interpretation of the inscription presented in this paper was based on those studies mentioned above with a few revisions. 
[Interpretation]

In June, the leader of $\square$ 㔜 $\square$ 成 $\square$ 邦 report to you.

“....accomplished it ( $\square \square \square$ 成行之). The hood came and... with strength (淣巾來昏 $\square \square$ 也). The people working for 六 $\square$ 大城...60 days...(爲六 $\square$ 大城從人丁卒日). ... day came ... again ... ( $\square \square$ 走 $\square$ 日來 $\square \square \square$ 更 $\square$ 有干 $\square$ ). On the last day, the overseer was unable to assign and send this person to 烏 $\square$ 城 (卒日治之人此人烏 $\square$ 城置不行遣乙白).

The inscriptions on Chajŏn-No. 221 are unclear, and therefore there is a lot of room for objections and counterarguments to the deciphered characters and interpretation of the inscriptions. Likewise, the deciphered inscriptions and interpretation presented above also differ from earlier studies. However, all of the interpretations of the inscriptions of Chajŏn-No. 221 agree on one fact: Chajŏn-No. 221 was a wooden tablet document containing a report on a village leader who was unable to send a person who was recruited to work at a certain fortress.

The part of the inscription on Chajon-No. 221 that I would like to examine in this paper is the last two characters “交日” on side (2). In previous studies, “交日” was read as “六十巴” and understood as “65 people” (Lee Seung-jae 2013) or read as “交日” but “日” was interpreted separately and “交” was considered to refer to 60 people (Lee Yong-hyon 2015). However, “交日” is now understood as “60 days” during which people had to perform statute labor involving 六 $\square$ 大城 (six [missing one character] big fortresses), and this wooden tablet seems to be a report about a leader who was unable to send one of the laborers back even after the end of the 60-day period.

Before we further examine the inscriptions on this wooden tablet, it would be useful to discuss the legal system during the Tang dynasty. As indicated above, the term “代法 (literally, substitution law)” also does not appear in the Tang dynasty's legal system. However, for the interpretation of that term, we can refer to Tang Code, Article 239, Unauthorized levies 16, “A clause on the violation of the period of rotational labor (遣番代違 
Figure 2. Magnified photograph of the inscription “六日代法” on 17-No. $1^{53}$

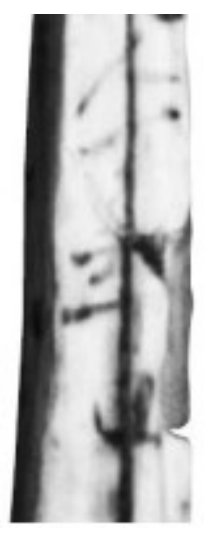

Figure 3. Magnified photograph of the inscription “人丁交日” on Chajŏn-No. $221^{54}$

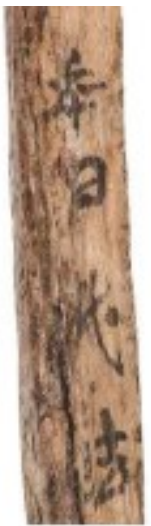

限條)”: “諸鎭戌應遣番代 而違限不遣者...” In the commentary for that particular law, the author cited “防人番代 皆十月一日交代” from the statute of military defense (軍防令), which contains the term “番代 (K. pŏndae)." According to Hanyu da cidian (漢語大詞典), the most comprehensive Chinese dictionary to date, the definition of “番代” was "to change in turn," and in the above article of the Tang Code, the term was meant to refer to "shift rotation workers" or "work shift." This confirmed the fact that the character "代” was used in relation to shifts and rotations of border guards. If the understanding gleaned from the Tang Code is applied to 17-No. 1, “代法” could be understood as "a law that stipulates rotational work period for laborers," which hints at the possibility that the laborers had to perform statute labor on a 60 -day rotational schedule. ${ }^{55}$

53 Jung Su-Ock et al., Haman Sŏngsansansŏng Palguljosa Pogosŏ (IV-II): Mokkan Mit Mokchep'ump'yŏn (Report on the excavation of Sŏngsan Fortress in Haman (IV-II): wooden tablets and wooden items) (Changwŏn: Kungnip Kaya Munhwajae Yŏn'guso, 2011).

54 Press release from Cultural Heritage Administration, January 4, 2017.

55 Likewise, another scholar proposes that “六十日代法” was “a stipulation on 60-day 
The wooden tablets uncovered at Songsan Fortress were the first to provide some information on the length of statute labor in Silla. The inscription on the stele to Ch'ŏngje reservoir in Yŏngch'ŏn, which was erected in 798, stated that the total time spent on repairing the reservoir was from February 2 to April 13, involving 136 people who used axes and 14,140 laborers. However, it is unlikely that the laborers were sent to repair the reservoir all at the same time. Similarly, the stele built to commemorate the construction of Myŏnghwal Fortress built in 551 stated that the construction took all of 35 days, from November 15 to December 20. However, this record seems to refer only to part of the construction, and therefore it is difficult to assume that statute labor was performed only for 35 days. For a more indepth discussion, it would be helpful to examine a study that discusses the period of labor performed by statute laborers who were mobilized for the establishment of Namsan Sinsŏng Fortress. This study concludes that, while the specific number of days was unknown, laborers from each village were brought in at different points in time during the construction but served for the same amount of time. ${ }^{56}$

Along the same lines, Tang liu dian (唐六典), a collection of official statutes of the Tang dynasty, Vol. 2, the chapter on rites stipulates that: 1) the period of compulsory periodic labor was 20 days, 2) those who performed additional labor were exempted from paying field tax ( $\mathrm{zu}$, 租) and

labor period," based on the content of Chajŏn-No. 221. However, specifically, “代” was interpreted as "corresponding to" the 60-day statute labor or "relevant to the payment received for (the 60-day labor)." The study further argues that it is possible to interpret “代” to mean that people performed 60-day rotational labor or that it was a stipulation on substitution of workers. As for the former possibility, the idea is not explored further, and the latter idea of worker substitution is deemed unlikely. Kim Chang-seok, "Haman Sŏngsansansŏng 17ch'a Palguljosa Ch'ult'o Samyŏnmokkan (23pŏn)e Kwanhan Sigo,” 139-47.

56 Ha Il-Sik, "6segi Mal Sillaŭi Yŏgyŏk Tongwŏn Ch'egye: Namsansinsŏngbiŭi Kijaeyangsige Taehan Chaegŏmt'o (Silla's labor mobilization system in the late sixth century: a reexamination of the format of inscriptions on the steles of Namsan Sinsŏng Fortress)," Yǒksawa Hyŏnsil 10 (1993): 225-6. 
household tax (diao, 調), and 3) the laborers were not allowed to serve for more than 50 days. Although the existence of compulsory periodic labor in Silla has not been confirmed, the "60-day taebŏp" found on a Sŏngsan Fortress wooden tablet seems too demanding in light of the Tang dynasty law. However, considering the fact that tax revenues from not only the surrounding regions but also Sangju were poured into Sŏngsan Fortress at Haman, it seems that Silla pooled together and deployed human and material resources at the state level to administer the former territory of Ara Kaya, which became incorporated into Silla around that time. Under these circumstances, it is plausible that laborers were mobilized for 60 days at a time. In addition, the terms "sŏnjŏl (先節, early phase)" and "hoepöp thirty days" seem to suggest that the 60-day law was not necessarily fixed but applied flexibly, which means that 60-day labor probably was not compulsory labor. In any case, it seems evident that the "substitution law (taebŏp, 代法)" was used as a legal term referring to the labor rotation period throughout regional communities as well.

Then what kind of labor did people partake in when they were mobilized through the 60-day taeböp? The inscriptions on 17-No. 1 do not provide any information on the kind of labor people were to perform. One study proposes that according to the inscriptions on Chajŏn-No. 221, people had been recruited to build a fortress. ${ }^{57}$ Considering the existence of tugŏn (兒巾) or the circumstances in which certain laborers who were working for a fortress were deployed to a new fortress, it seems safe to assume that the laborers had been mobilized to erect a fortress. ${ }^{58}$

In terms of the people's names on 17-No. 1, there are similarities between the wooden tablet and the steles of Namsan Sinsŏng Fortress when we apply the categorization method used for the inscriptions on the steles. People's names mentioned on the steles of Namsan Sinsŏng Fortress are

57 Lee Seung-jae, "Haman Sŏngsansansŏng 221ho Mokkanŭi Haedok," 16-7.

58 Kim Chang-seok argues that the 60-day labor period included both statute and military labor. Kim Chang-seok, "Haman Sŏngsansansŏng 17ch'a Palguljosa Ch'ult'o Samyŏnmokkan (23pŏn)e Kwanhan Sigo," 143. 
Table 2. Categorization of People's Names on 17-No. 1 from Sŏngsan Fortress in Haman and Namsan Sinsŏng Fortress Stele No. 1

\begin{tabular}{|c|c|c|c|c|c|}
\hline & $\begin{array}{c}\text { Sŏngsan Fortress, } \\
\text { Haman } \\
\text { 17-No. } 1\end{array}$ & \multicolumn{4}{|c|}{$\begin{array}{c}\text { Namsan Sinsŏng Fortress } \\
\text { Stele No. } 1\end{array}$} \\
\hline Group A & $\begin{array}{c}\text { 弥即余智 大舍 下智 } \\
\text { (Mijŭkiji taesa haji) }\end{array}$ & $\begin{array}{c}\text { 阿良邏頭 } \\
\text { (Aryang Nadu) } \\
\text { 奴含道使 } \\
\text { (Noham Tosa) } \\
\text { 營沽道使 } \\
\text { (Yŏnggo Tosa) }\end{array}$ & $\begin{array}{l}\text { 沙喙 } \\
\text { 沙咟 } \\
\text { 沙嗀 }\end{array}$ & $\begin{array}{l}\text { 音乃古 } \\
\text { 含親 } \\
\square \square \square \text { 知 }\end{array}$ & $\begin{array}{c}\text { 大舍 } \\
\text { (taesa) } \\
\text { 大舍 } \\
\text { (taesa) } \\
\text { 大舍 } \\
\text { (taesa) }\end{array}$ \\
\hline Group B & $\begin{array}{c}\text { 眞乃滅 村主 } \\
\text { (Chinnaemyŏl village } \\
\text { leader) }\end{array}$ & $\begin{array}{l}\text { 郡上村主 } \\
\text { 匠尺 } \\
\text { 文尺 }\end{array}$ & $\begin{array}{l}\text { 阿良村 } \\
\text { 染吐 } \square \\
\text { 阿良村 } \\
\text { 奴含村 }\end{array}$ & $\begin{array}{c}\text { 今知 } \\
\square \text { 知尔利 } \\
\text { 末丁次 } \\
\text { 次 } \square \square \text { 禮 } \\
\square \text { 文知 }\end{array}$ & $\begin{array}{l}\text { 撰干 } \\
\text { 上干 } \\
\text { 干 } \\
\text { 干 } \\
\text { 阿尺 }\end{array}$ \\
\hline Group C & $\begin{array}{c}\text { 伊他罹 及伐尺 } \\
\text { (It'angni Kŭppŏlch’ŏk) }\end{array}$ & $\begin{array}{c}\text { 城使上 } \\
\square 尺 \\
\square \text { 文尺 } \\
\text { 面捉上 } \\
\text { 門捉上 } \\
\square \text { 捉上 } \\
\text { 小石捉上 }\end{array}$ & 阿良 & $\begin{array}{c}\text { 沒奈生 } \\
\text { 阿 } \square \square \text { 次 } \\
\text { 竹生次 } \\
\text { 珍巾 } \square \\
\text { 知禮次 } \\
\text { 首尔次 } \\
\text { 辱テ次 }\end{array}$ & $\begin{array}{l}\text { 上 } \square \\
\text { 干 } \\
\text { 一伐 }\end{array}$ \\
\hline
\end{tabular}

generally categorized into three groups-A, B, and C. Group A consisted of officials dispatched by the central government to local regions, who were in charge of the construction of fortresses, assigned to deliver orders from the state, and commanded and directed the supervisors in Group B and low-ranking officials in Group C; Group B consisted of construction supervisors who were under the command of regional officials in Group A; Group C consisted of low-ranking officials. Laborers were not mentioned in the inscriptions. ${ }^{59}$ The following is the categorization of the

59 This categorization method was first attempted by Lee Jong-Wook in 1974 . The role and characteristics of each group have been accepted in later studies without major changes in the larger framework. Lee Jong-Wook, "Namsansinsŏngbirŭl T'onghayŏ Pon Sillaŭi Chibangt'ongch'ich'eje (Silla's regional governing system as seen through the steles of Namsan Sinsŏng Fortress)," Yǒksahakpo 64 (1974). 
names that appear in the inscriptions on 17-No. 1, using the same method as for the steles of Namsan Sinsǒng Fortress:

Mijŭkiji taesa haji (弥郎尔智 大舍 下智) belonged to Group A. Although the meaning of haji (下智) is yet uncertain, Mijŭkiji was a taesa (大 舍), the 12th of the 17 government official ranks, and considering the fact that he was at a fortress, it is likely that he was an official who was sent to a regional place by the central government. Nadu (邏頭) and Tosa (道使), who belong to Group A and whose names appear in the inscriptions of Namsan Sinsŏng stele No. 1, are also taesa. The Chinnaemyŏl village leader belongs to Group B. Among the people whose names are mentioned on Namsan Sinsonng stele No. 1, people who belong to Group B are a group of supervisors who mobilized people of villages to participate in the construction of the fortress by the order of local officials. In consideration of the report written on 17-No. 1, the sender and the recipient of the report, the leader of Chinnaemyŏl village seems to be an intermediary manager who took part in mobilizing and supervising laborers. For the same reason, the leader of $\square$ 㔜 $\square$ 城 $\square$ 邦 village mentioned on Chajŏn-No. 221 is assumed to belong to Group B. It'angni Kŭppŏlch'ŏk belongs to Group C, as he was a low-ranking working-level official. Küppǒlch'ŏk was the lowest rank of the 12 local official ranks, which had disappeared by the time the steles of Namsan Sinsorng were erected. ${ }^{60}$ It corresponded to Sanggan, sixth of the 12 local official ranks, and other lower ranking posts as well as those without official posts found on the inscriptions of Namsan Sinsŏng stele No. 1. Also, we can glean that kŭppǒlch'ǒk was lower in rank compared to the leader of Chinnaemyorl village, since the former reported to the latter.

These inscriptions show that the labor mobilization system, for which the administrative villages were the basic units as seen on the steles of Namsan Sinsŏng Fortress erected in the late sixth century, had already been in place at the time Songsan Fortress was built in the mid-sixth cen-

60 Yoon Seon-Tae, "Sillaŭi Ch'oki Oewich'ekyewa 'Kŭppŏlch'ŏk'," 162-72. 
tury. ${ }^{61}$ Other information was also deduced from the comparison between the steles of Namsan Sinsŏng Fortress and wooden tablets from Sŏngsan Fortress. For instance, the steles of Namsan Sinsŏng Fortress indicated that officials in Group A did not remain on the construction site the entire time. $^{62}$ As for the wooden tablets found at Sŏngsan Fortress, “ $\square$ 城 ( $\square$ fortress)" where Mijŭkiji taesa was reported to be according to the two wooden tablets is assumed to be Songsan Fortress, since the wooden tablets were excavated there; and scholars also speculate that labor was mo-

61 One scholar argues that the labor mobilization system and document administration as gleaned from Sŏngsan Fortress were more similar to those found on the Myŏnghwal Fortress (551) stele than those found on Namsan Sinsŏng Fortress (591) steles. According to this theory, at the time the Myŏnghwal Fortress stele was erected, laborers were mobilized at the kun (郡) or county level. Scribes (sŏsain, 書 寫人) were found at the county level as well. However, at the time the Namsan Sinsŏng Fortress munuments were erected, scribes (munch'ŏk, 文尺) were also found at the fortress (城) and village (村) levels, which were smaller than counties. Moreover, the study asserts that the change in the title of scribes hinted that their previously tentative position was changed to an administrative one. Hashimoto Shigeru, 韓國古代木簡の研究 (A study on ancient Korean wooden tablets) (Tokyo: Yoshikawa Kobunkan, 2014), 75-7. In terms of the labor mobilization system, the study speculates that as a certain ch'on within the same kun was mentioned far more often than others on Sŏngsan Fortress wooden tablets, the labor mobilization system was closer to the time the Myŏnghwal Fortress stele was erected, when labor mobilization within a kun was entrusted to the leader of a central ch'on within the kun, rather than the time the Namsan Sinsŏng Fortress steles were erected, when the burden of labor had been evenly imposed on all the villages. Hashimoto Shigeru, "Chunggogi Silla Ch'uksŏngbiŭi Yŏn'gu (A study on the steles for the construction of fortresses in Silla in the mid-ancient period)," Tongguk Sahak 55 (2013): 174. However, “乌烏大谷” (odaegok), which was the unit of labor mobilization on the Myŏnghwal Fortress stele, is considered to be an administrative village (haengjŏng ch'on) rather than a kun. Ju Bo-don, "Myŏnghwalssansŏngjejakpiŭi Yŏgyŏktongwŏnch'ejewa Ch'ollak (The Labor Mobilization System and Villages on the Incription of the Stele of Myŏnghwal Fortress)," in Kŭmsŏngmun'gwa Sillasa (Epigraphs and the history of Silla) (Seoul: Chisiksanŏpsa, 2002), 206-9.

62 Ha Il-Sik, “6segi Mal Sillaŭi Yŏgyŏk Tongwŏn Ch'egye,” 209. 
bilized for the construction of the fortress. Moreover, there were mentions of the taesa visiting other fortresses, such as “六 $\square$ 大城” and “烏 $\square$ 城," according to Chajŏn-No. 221, and it seems plausible that these other fortresses were also being constructed at the time. Therefore, both ChajonNo. 221 and 17-No. 1 are considered wooden tablet documents that contain the reports filed by village leaders, who supervised the construction of Sorngsan Fortress and other fortresses in the region, to the taesa, their supervisor, who had been dispatched by the central government and staying at Sŏngsan Fortress.

The image of Silla in the mid-sixth century as deduced from the inscriptions of 17-No. 1 is as follows: first, documents were an integral part of Silla's administration even on the regional level; second, “ (taebŏp, 代 法)" was a law that stipulated the length of labor for each rotation, and the labor period was 60 days for each rotation for the construction of Sŏngsan Fortress; third, the labor mobilization system whose basic unit was the village had already been established in the mid-sixth century. This evidence shows that a strict regional government system managed by law and administered with documents had already been in place at the time. Furthermore, the mention of taesa, an official rank that was first confirmed on the Sŏngsan Fortress wooden tablets, shows that Sŏngsan Fortress was under direct control of the central government.

\section{Conclusion}

This study examines the status of research on wooden tablets excavated from Sŏngsan Fortress in Haman and analyzes the wooden tablet documents that were recently described in an official report.

From 1991 to 2016, Sorngsan Fortress was excavated by the Kaya National Research Institute of Cultural Heritage, and a total of 314 wooden tablets were discovered. Based on the marks of local official ranks (oewi) that appear on the tablets and the time of Silla's advancement into Ara Kaya, the period in which these wooden tablets were created is presumed 
to be around mid-sixth century. The content of these tablets tends to be listed in the following format: "region, name of a person, name of the product, and amount." Most of the tablets are labels (hach'al mokkan), with the exception of a few, which were created for the purpose of documentation or for other reasons.

The place names that appear on the wooden tablets were regions under the jurisdiction of Sangju (上州), the present-day northern area of North Kyǒngsang Province. As this area was located along the Nakdong River system, Silla seems to have administered or governed the areas that used to be part of Old Kaya, and also collected taxes from those regions through the waterways of the Nakdong River. The detailed categorization of place names on the wooden tablets facilitates a better understanding of the characteristics and structures of the villages (ch'on, 村) at that time. Spontaneously formed villages, or "natural villages" (chayǒnch'on, which are distinguished from villages formed for administrative purposes) were the basic unit of tax collection. The discovery of additional wooden tablets has led to a clarification of the meaning of the character “負 (pu)," recorded on several tablets, and has also intensified the discussion on the nature of "noin."

In addition, this study examines and speculates on the image of midsixth century Silla through two wooden tablets that were recently discovered-17-No. 1 and Chajŏn-No. 221. From these wooden tablets, I was able to confirm that "taebŏp (代法) was a law that stipulated the amount of time laborers were to perform statute labor for each rotation, and that people worked for 60 days at a time for the construction of Sŏngsan Fortress. Also, the labor mobilization system with the village as a basic unit, which was found in the inscriptions on the steles of Namsan Sinsorng had already been established in the mid-sixth century, and document administration had been implemented even in regional parts of Silla. This evidence points to the idea that a strict regional government system based on document administration and laws had been established at the time.

In conducting a thorough examination of individual studies for the literature review, I relied on earlier publications that have organized studies 
on wooden tablets excavated from Sŏngsan Fortress, and also reviewed recent studies on Sŏngsan Fortress wooden tablets that have been compiled since the last publication on the history of research on wooden tablets was published in order to paint a clearer picture of mid-sixth century Silla. Unfortunately, it was not possible to explain every single important research achievement due to a lack of time and space. Also, I understand that I might have jumped to conclusions regarding the inscriptions on the wooden tablets out of my enthusiasm for research since accurate images and deciphered inscriptions have yet to be released. However, I believe that the significance of this study lies in the possibility it presents regarding the deciphering and interpretation of the inscriptions. I hope that Wooden tablets of Ancient Korea II, which is due to be published this year, will bring clarity to the issue of the confusing numbering of Sorngsan Fortress wooden tablets, provide higher resolution infrared photographs of the wooden tablets, and become the cornerstone and pillar of research on Sŏngsan Fortress wooden tablets in the future. I would like to conclude this paper with the hope that I will be able to reexamine the wooden tablets again later.

\section{References}

1. Choi, Jang-mi. "Haman Sŏngsansansŏng Palguljosa Sŏnggwawa Ch'ult'o Mokki Kŏmto (Results of the excavation and research of Sŏngsan Fortress and a review of the excavated wooden vessels)." Paper presented at the Conference 〈Sŏnsawa Kotae Mokki. Mokkanŭi Ch'oesin Yŏn'gu Hyŏnhwanggwa Kwache (Latest trends and challenges in the research of prehistoric and ancient wooden vessels and wooden tablets) $>$ by Kaya National Research Institute of Cultural Heritage \& Pokchŏn Museum, Pusan, South Korea, June 24, 2016.

2. Ha Il-Sik. "6segi Mal Sillaŭi Yŏgyŏk Tongwŏn Ch'egye: Namsansinsŏngbiŭi Kijaeyangsige Taehan Chaegŏmt'o (Silla’s labor mobilization system in the late sixth century: a reexamination of the format of inscriptions on the steles of Namsan Sinsong Fortress)." 
Yŏksawa Hyŏnsil 10 (1993): 199-230.

3. Hirakawa, Minami. “Ilbon'godaemokkan Yŏn'guŭi Hyŏnhwanggwa Sinsijŏm (Current trends and new implications of research on ancient Japanese wooden tablets)." Han'gukkodaesayŏn'gu (The Journal of Ancient Korean History) 19 (2000): 123-54.

4. Hashimoto, Shigeru. “城山山城木簡と六世紀新羅の地方支配 (Wooden tablets from Sŏngsan Fortress and Silla's regional ruling system in the sixth centurya).” In 東アジア古代出土文字資料の研究 (A study on the excavated historical documents and records of ancient East Asia), edited by Kudo Modoo \& Lee Sungsi. Tokyo: Yuzankaku, 2009.

5. Hashimoto, Shigeru. "Chunggogi Silla Ch'uksŏngbiŭi Yŏn'gu (A study on the steles for the construction of fortresses in Silla in the mid-ancient period).” Tongguk Sahak 55 (2013): 129-82.

6. Hashimoto, Shigeru. 韓國古代木簡の研究 (A study on ancient Korean wooden tablets). Tokyo: Yoshikawa Kobunkan, 2014.

7. Jeon, Deog-Jae. "Haman Sŏngsansansŏng Mokkanŭi Naeyonggwa Chunggogi Sillaŭi Such'wich'egye (Contents of wooden tablets found at Sŏngsan Fortress in Haman and the tax collection system in Silla in the mid-ancient period)." Yŏksawa Hyŏnsil 65 (2007): 223-51.

8. Jeon, Deog-Jae. "Haman Sŏngsansansŏng Mokkanŭi Yŏn'gu Hyŏnhwanggwa Chaengjŏm (Research Trends and Debates on Wooden Tablets from Haman Sŏngsan Fortress)." Sillamunhwa 31 (2008): 1-35.

9. Jeon, Deog-Jae. "Haman Sŏngsansansŏng Ch'ult'o Silla Hach'almokkanŭi Hyŏngt'aewa Chejakchiŭi Kŏmt'o (The form and places of production of wooden tablet labels excavated from Sŏngsan Fortress in Haman)." Mokkan'gwa Munja (Wooden Documents and Inscriptions Studies) 3 (2009): 63-101.

10. Ju, Bo-don. "Myŏnghwalssansŏngjejakpiŭi Yŏgyŏktongwŏnch'ejewa Ch'ollak (The Labor Mobilization System and Villages on the Incription of the Stele of Myŏnghwal Fortress)." In Han'guksahangnonch'ong (A collection of papers on Korean history), edited by 
Sŏamjohangnaegyosu Hwagapkinyŏmnonch'ong Kanhaengwiwŏnhoe. Seoul: Aseamunhwasa, 1992. [republished in Kŭmsŏngmun'gwa Sillasa (Epigraphs and the history of Silla). Seoul: Chisiksanŏpsa, 2002].

11. Ju, Bo-don. "Haman Sŏngsansansŏng Ch'ult'o Mokkanŭi Kich'ochŏk Kŏmto (A basic review of wooden tablets excavated from Sŏngsan Fortress in Haman).” Han'gukkodaesayŏn'gu (The Journal of Ancient Korean History) 19 (2000): 41-75.

12. Kim, Chang Ho. "Haman Sŏngsansansŏng Ch'ult'o Mokkane Taehayŏ (On the wooden tablets excavated from Haman Sŏngsan Fortress).” In Haman Sŏngsansansŏng (Sŏngsan Fortress of Haman), edited by Kungnip Ch'angwŏn Munhwajae Yŏn'guso (Changwon National Research Institute of Cultural Heritage). Ch'angwŏn: KCMY, 1998).

13. Kim, Chang-seok. "Silla Chunggogiŭi Noin'gwa Nobi: Sŏngsansansŏng Mokkan'gwa 'Pongp'yŏngbi'ŭi Punsŏgŭl Chungsimŭro [Silla's noin (奴人) and nobi (奴婢) in the mid-ancient period: based on the analysis of wooden tablets found at Sŏngsan Fortress in Haman and the Silla stele in Pongp'yŏng].” Han'gukkodaesayŏn'gu (The Journal of Ancient Korean History) 54 (2009): 43-83.

14. Kim, Chang-seok. "Haman Sŏngsansansŏng Mokkanŭl T'onghae Pon Sillaŭi Chibangsahoe Kujowa Such'wi (The Structure of Regional Societies and the Tax Collection System of Silla according to the Wooden Tablets from Sŏngsan Fortress in Haman)." Paekchemunhwa 54 (2016): 145-77.

15. Kim, Chang-seok. "Haman Sŏngsansansŏng 17ch'a Palguljosa Ch'ult'o Samyŏnmokkan (23pŏn)e Kwanhan Sigo [A study on the four-sided wooden tablet (No. 23) discovered in the seventeenth excavation of Sŏngsan Fortress in Haman]." Han'guksayŏn'gu (The Journal of Korean History) 177 (2017): 126-50.

16. Kim, Jae Hong. 'Haman Sŏngsansansŏng Ch'ult'o Mokkan'gwa Ch'ollaksahoeŭi Pyŏnhwa (Wooden tablets from Sŏngsan Fortress in Haman and the changes in local societies)." Kuksagwannonch'ong 
(Treatises on Korean history) 106 (2005): 55-75.

17. Kim, Tae-Sik. "Haman Annakukŭi Sŏngjanggwa Pyŏnch'ŏn (The growth and transformation of Ara Kaya in Haman." Han'guksayŏn'gu (The Journal of Korean History) 86 (1998): 29-70.

18. Kwon, In-han. 'Kodae Chimyŏnghyŏngt'aeso 'ponp'a/ponp'i'e Taehayŏ (On the morphemes 'ponp'a/ponp'i (本波/本彼)' in ancient place names).” Mokkan'gwa Munja (Wooden Documents and Inscriptions Studies) 2 (2008): 83-95.

19. Lee, Jong-Wook. 'Namsansinsŏngbirŭl T'onghayŏ Pon Sillaŭi Chibangt'ongch'ich'eje (Silla's regional governing system as seen through the steles of Namsan Sinsŏng Fortress)." Yǒksahakpo 64 (1974): 1-69.

20. Lee, Ju-Heun. 'Haman Sŏngsansansŏng Puyŏpch'unggwa Ch'ultoyumurŭi Kŭmto (An Examination of the Leaf-paved Layer and Excavated Relics from Haman Sŏngsan Fortress)." Chunganggokoyŏn'gu (Journal of the Central Institute of Cultural Heritage) 16 (2015): 75-103.

21. Lee, Kyoung-sup. "Haman Sŏngsansansŏng Mokkanŭi Yŏn'gu Hyŏnhwanggwa Kwache (Trends and Prospects of Research on Wooden Tablets from Sŏngsan Fortress in Haman)." Sillamunhwa 23 (2004): 205-28.

22. Lee, Kyoung-sup. "Sŏngsansansŏng Ch'ult'o Hach'al Mokkanŭi Chejakchiwa Kinŭng [The origin of production and use of wooden tablet labels (hach'al mokkan) excavated from Sŏngsan Fortress]." Han'gukkodaesayŏn'gu (The Journal of Ancient Korean History) 37 (2005): 113-56.

23. Lee, Kyoung-sup. “Sŏngsansansŏng Ch'ult'o Silla Chimkkorip'yo (荷 札) Mokkanŭi Chimyŏng Munjewa Chejak Tanwi (The issue of toponymy found on wooden labels from Silla excavated from Sŏngsan Fortress)." Sillasahakpo 23 (2011): 535-78.

24. Lee, Kyoung-sup. “Sillaŭi Noin [Silla’s noin (奴人)].” Han'gukkodaesayŏn'gu (The Journal of Ancient Korean History) 68 (2012): 197-234. 
25. Lee, Kyoung-sup. "Haman Sŏngsansansŏng Ch'ult'o Silla Mokkan Yŏn'guŭi Hŭrŭmgwa Chŏnmang (Research Trends and Prospects of Silla Dynasty Wooden Tablets Excavated from Sŏngsan Fortress in Haman)." Mokkan'gwa Munja (Wooden Documents and Inscriptions Studies) 10 (2013): 77-93.

26. Lee, Seung-jae. "Haman Sŏngsansansŏng 221ho Mokkanŭi Haedok (Decoding the inscriptions on wooden tablet No. 221 from Sŏngsan Fortress in Haman)." Han'gungmunhwa (Korean culture) 61 (2013): 3-32.

27. Lee, Su Hun. 'Haman Sŏngsansansŏng Ch'ult'o Mokkanŭi Pisŏkkwa $\mathrm{Pu}$ [P'isŏk (稗石) and $\mathrm{pu}$ (負) on wooden tablets excavated from Sŏngsan Fortress in Haman]." Chiyŏkkwa Yǒksa 15 (2004): 5-40.

28. Lee, Su Hun. "Sŏngsansansŏng Mokkanŭi 'Ponp'a'wa 'Malna'. Ana' (“本波,' ‘末那, ' and ‘阿那” in wooden tablets of Sŏngsan Fortress).” Yŏksawa Segye (History and the World) 38 (2010): 113-44.

29. Lee, Su Hun. "6segi Silla Noinŭi Sŏnggyŏk [The nature of noin (奴 人) in sixth century Silla]." Han'gungminjongmunhwa (Journal of Koreanology) 52 (2014): 33-57.

30. Lee, Sungsi. “Han'guk Mokkanyŏn'guŭi Hyŏnhwanggwa Haman Sŏngsansansŏng Ch'ult'oŭi Mokkan (Research trends on Korean wooden tablets and wooden tablets excavated from Sŏngsan Fortress in Haman)." Han'gukkodaesayŏn'gu (The Journal of Ancient Korean History) 19 (2000): 77-121.

31. Yi, Yonghyŏn (Lee, Yong-hyun). "Han'gukkotae Mokkanyŏn'gu (A study of Korea's ancient wooden tablets).” PhD diss., Korea University, 2001.

32. Lee, Yong-hyun. “Haman Sŏngsansansŏng Ch'ult'o Mokkan'gwa Yukseki Sillaŭi Chipanggyŏngyŏng (Wooden tablets excavated from Sŏngsan Fortress in Haman and regional administration in sixthcentury Silla).” Tongwŏnhaksul Nonmunjip 5 (2003): 27-66.

33. Lee, Yong-hyun. "Haman Sŏngsansansŏng Ch'ult'o Mokkan (Wooden tablets excavated from Sŏngsan Fortress in Haman)." In Han'gugǔi Kodaemokkan (Wooden tablets of Ancient Korea), edited 
by Kungnip Ch'angwŏn Munhwajae Yŏn'guso (Changwon National Research Institute of Cultural Heritage). Ch'angwŏn: KCMY, 2004.

34. Lee, Yong-hyun. "Haman Sŏngsansansŏng Ch'ult'o Mokkanŭi Sŏnggyŏngnon: 2ch'a Pogobunŭl Chungsimŭro (A theory on the characteristics of wooden tablets excavated from Sŏngsan Fortress in Haman: a review of the second excavation report)." Kogohakji 14 (2005): 115-46.

35. Lee, Young-hyun. "Haman Sŏngsansansŏng Ch'ult'o Mokkan 221hoŭi Kugŏhakchŏk Ǔiŭi (The linguistic significance of wooden tablet No. 221 excavated from Sŏngsan Fortress in Haman).” Kugyŏryŏn'gu (Kugyol Studies) 34 (2015): 41-63.

36. Nam, Jae Woo. Allakuksa (History of Ara Kaya). Seoul: Hyean, 2003.

37. Noh, Choong Kook. "Sillaŭi Noinch'on: 'Uljinbongp'yŏngsillabi'rŭl Chungsimŭro [Silla's noinch'on (noin village): Silla stele in Pongp'yŏng, Uljin].” Taegusahak (The Taegu Historical Review) 125 (2016): 1-30.

38. Park, Jong Ik. "Haman Sŏngsansansŏng Palguljosawa Mokkan (Wooden tablets and excavation of Sŏngsan Fortress in Haman)." Han'gukkodaesayŏn'gu (The Journal of Ancient Korean History) 19 (2000): 5-39.

39. Park, Jong Ik. "Haman Sŏngsansansŏng Ch'ult'o Mokkanŭi Sŏnggyŏk Kŏmt'o (A review of the characteristics of wooden tablets excavated from Sŏngsan Fortress in Haman)." Han'gukkogohakpo (Journal of the Korean Archaeological Society) 48 (2002).

40. Park, Jong-ki. “Han'guk Kodaeŭi Noin'gwa Pugok [Noin (奴人) and Pugok (部曲) in ancient Korea].” Han'gukkodaesayŏn'gu (The Journal of Ancient Korean History) 43 (2006): 129-68.

41. Son, Hwan Il. 'Haman Sŏngsansansŏng Ch'ult'o Mokkanŭi Ǔimiwa Sŏch'e (The meaning and typography of wooden tablets excavated from Sŏngsan Fortress in Haman-gun)." Han'guksahaksahakpo (The Korean History Journal of Historiography) 35 (2017): 5-30.

43. Yoon, Sang-deok. "Haman Sŏngsansansŏng Ch'ucho Yŏndaee 
Kwanhayŏ (A Consideration on the Construction Date of Seongsan Sanseong Fortress in Haman)." Mokkan'gwa Munja (Wooden Documents and Inscriptions Studies) 14 (2015): 75-96.

43. Yoon, Seon-Tae. "Haman Sŏngsansansŏng Ch'ult'o Silla Mokkanŭi Yongdo (The use of wooden tablets from Silla excavated from Sŏngsan Fortress in Haman)." Chindan Hakpo 88 (1999): 3-24.

44. Yoon, Seon-Tae. "Silla Chunggokiŭi Ch'on'gwa To: Ǔmnagi Haech'ewa Kwallyŏnhayŏ [Ch'on (村) and to (徒) in Silla during the sixth and seventh centuries: on the dissolution of Ümnak]." Han'gukkodaesayŏn'gu (The Journal of Ancient Korean History) 25 (2002): 131-70.

45. Yoon, Seon-Tae. "Haman Sŏngsansansŏng Ch'ult'o Silla Hach'alŭi Chaekŏmto [Revisiting Silla's labels (hach'al) excavated from Sŏngan Fortress in Haman]." Sarim 41 (2012): 147-78.

46. Yoon, Seon-Tae. "Sillaŭi Ch'oki Oewich'ekyewa 'Kŭppŏlch'ŏk' (Local government posts system in early Silla and kŭppǒlch'ǒk)." Tongguk Sahak 61 (2016): 157-85.

47. Yoon, Seon-Tae. 'Han'guk Kotae Mokkanŭi Yŏn'guhyŏnhwanggwa Kwaje (Research and perspectives on the wooden documents of ancient Korea)." Sillasahakpo 38 (2016): 387-421.

48. Xie, Guihua. "Chunggugesǒ Ch'ult'odoen Wijindae Ihuŭi Hanmun'kanjimunsǒwa Sŏngsansansŏng Ch'ult'o Mokkan (Chinese documents from the Wei and Jin dynasties found in China and wooden tablets discovered in Sŏngsan Fortress)." Han'gukkodaesayŏn'gu (The Journal of Ancient Korean History) 19 (2000): 155203. 
$<$ Abstract $>$

\section{A Study of Past Research on Sŏngsan Fortress Wooden Tablets and an Examination of Excavated Wooden Tablet Documents}

Nari Kang

This paper examines past research on wooden tablets (mokkan) excavated from Sŏngsan Fortress in Haman and attempts to provide a new interpretation of wooden tablet documents (munsŏ mokkan) that have been recently discovered.

Up until last year (2016), a total of 314 wooden tablets have been excavated from Sŏngsan Fortress in Haman. They were produced in various regions around the mid-sixth century. Most were wooden tablet labels (hach'al mokkan), which contained the following information in the same format: "place name, person's name, item, and the amount of items." The place names found on the wooden tablets were under the jurisdiction of Sangju (上州), showing that Silla administered the territories that once belonged to Kaya and collected taxes from different regions, which were brought to Haman through the waterways of the Nakdong River. The discovery of additional wooden tablets has advanced the understanding of the structure and nature of ch'on (village, 村) as well as the meaning of “負” (pu), and intensified the debate on the nature of noin (奴人).

It was also possible to speculate on the state of society in Silla through the recently discovered wooden tablets, 17-No. 1 and Chajŏn-No. 221. This study was able to confirm that "taebŏp" (代法) was a stipulation on the length of statute labor workers performed for each rotation, and that workers were mobilized for the construction of Sŏngsan Fortress for 60 days at a time. Moreover, this study speculates that the labor mobilization system, whose basic unit was $c h$ 'on, was already established in the mid-sixth century, and that the document administration of regional governments in Silla were in practice as well. 
Keywords: Sǒngsan Fortress in Haman, mokkan, wooden tablets, hach'al, labels, munsǒ mokkan, wooden tablet documents, mandate, fundamental laws, and statute labor 


\section{〈국문 초록〉}

\section{함안 성산산성 출토 목간의 연구 현황과 문서목간 再考}

강나리 (고려대 한국사학과 박사과정수료)

본고는 함안 성산산성 출토 목간의 연구 현황을 살펴보고, 최근에 보고된 문서 목간의 새로운 해석을 시도한 글이다.

함안 성산산성에서 2016년까지 모두 314점의 목간이 출토되었다. 이는 대체로 6 세기 중엽에, 각 지역에서 제작된 것이다. 대부분 하찰목간이며, 그 기본 서식은 ‘지명+인명+물품명+수량’이다. 목간의 지명들은 上州의 관할지역으로, 낙동강 수 로를 이용하여 각지의 세금을 함안에 집결시켜 옛 가야지역을 경영하였음을 알 수 있다. 목간의 추가 발굴에 따라 村의 성격· 구조 및 '負”의 의미 이해에 진전 이 있었으며, ‘奴人’의 성격 규명 논의는 심화되었다.

한편, 최근 보고된 17차-1호와 자전-221호를 통해 신라 사회 모습을 간취할 수 있다. '代法’은 '역역 동원에 대한 교대 기간을 규정한 법률'이며, 성산산성에서는 60 일을 주기로 축성의 역에 동원되었음을 확인하였다. 또 남산신성비에 보이는 촌을 단위로 한 역역동원체계가 6세기 중반에 이미 갖추어져 있었으며, 신라 지 방사회까지 문서행정이 시행되고 있었음을 추정하였다.

주제어: 함안 성산산성, 목간, 하찰, 문서목간, 율령, 대법(代法), 역역동원(力役 動員) 